\title{
The United Kingdom (UK)
}

\begin{abstract}
The UK is the possessor of the world's oldest and largest DNA database by proportion of population: the National Criminal Intelligence DNA Database, established in 1995. As a nation-state that holds one of the world's largest DNA databases, the UK has been dealing systematically with the societal effects triggered by various ethical controversies. In terms of bordering practices, the UK serves as an example of an ambivalent mode of re-and debordering. This ambivalence derives from the UK's changing position regarding the Prüm system. In 2014, the UK government, driven by the parliament, decided to opt out of the Prüm Decisions. In 2015, after a Prüm-style pilot project run with other EU Member States, the UK decided to opt in. This decision, nonetheless, included the imposition of limits on other EU countries' access to the UK's data. Consequently, the UK's debordering practices co-exist with rebordering attempts aimed at restricting access to their own data.
\end{abstract}

Keywords UK $\bullet$ DNA database $\bullet$ Data exchange $\bullet$ Re- and debordering • Prüm 


\section{INTRODUCTION}

Established in 1995, the UK's National Criminal Intelligence DNA Database (NDNAD) is believed to be the oldest national forensic DNA database (Downey, Stephens, \& Flaherty, 2012; Johnson \& Williams, 2007). ${ }^{1}$ According to the European Network of Forensic Science Institutes (ENFSI), in June 2016, the NDNAD contained 4,733,755 profiles of individuals in the DNA database. ${ }^{2}$ This represented 8.8 per cent of the resident population. More recent data shows that, on 31 March 2020, the number of subject profiles held had increased to more than 6 million $^{3}$ and that the database held more than 600,000 crime scene profiles. ${ }^{4}$ Holding the equivalent of about 10 per cent of the UK's resident population ${ }^{5}$ (of $\left.67,879,488^{6}\right)$, the NDNAD is the world's largest database by proportion of population (Amankwaa, 2018).

The UK's assimilation into the Prüm system for the transnational exchange of DNA data for police and judicial cooperation in the European Union (EU) has not been straightforward. In December 2014, the UK decided to withdraw from the Prüm system. However, after running tests with the Netherlands, Spain, France and Germany, it decided to rejoin Prüm in 2015. However, there were successive delays, in which the uncertainties emerging around Brexit played a role, and the UK only became

\footnotetext{
${ }^{1}$ In the UK, the National Criminal Intelligence DNA Database (NDNAD) is used solely for criminal investigation purposes. Other forensic purposes, such as the identification of missing persons and unidentified body investigations, are managed by the UK Missing Persons Bureau, which has operated and maintained a Missing Persons DNA Database since May 2010 (Granja \& Machado, 2019).

${ }^{2}$ As the ENFSI report is to our knowledge the latest statistic which provides comparable information across countries, we refer to it to situate the UK in comparison to the other country cases in this study. Data available at http://enfsi.eu/wp-content/uploads/2017/01/ ENFSI-Survey-on-DNA-Databases-in-Europe-June-2016.pdf (last access on 23 June 2020).

${ }^{3}$ It is currently estimated that 14.1 per cent of the subject profiles held on the entire NDNAD are duplicates. Duplicate profiles arise when samples are taken from the same individual on more than one occasion. This may happen as a result of a person giving different names, or different versions of their name, during separate arrests. There may also be situations where a police force chooses to resample an individual (Home Office, 2019).

${ }^{4}$ National DNA Database statistics, Q4 2019 to 2020. Available at https://www.gov.uk/ government/statistics/national-dna-database-statistics (last access on 23 June 2020).

${ }^{5}$ We use the term 'the equivalent' because the NDNAD holds a significant number of duplicates (see footnote 3 ).

${ }^{6}$ Data available at https://www.worldometers.info/world-population/uk-population/ (last access on 23 June 2020).
} 
operational in 2019 (Council of the European Union, 2019). According to the latest DAPIX data, the UK is operational with seven countries (Council of the European Union, 2020). Developments on the path to Brexit made the UK's integration into the Prüm system additionally complex as the country current participation in the Prüm system ends on 31 December 2020. The UK is currently involved in the negotiation of an agreement that would allow the continuity of law enforcement and judicial cooperation in criminal matters. The UK is, therefore, addressed as an ambiguous mode of debordering.

The UK's cultural and political specificities also make the country's biobordering dynamics particularly interesting. The UK joined the European Community in 1973. During the negotiations for the Maastricht Treaty of 1992, the UK secured an opt-out from adopting the Euro as its official currency. In addition, in 1999, the UK also decided not to join the Schengen system. This special status was secured by a legally binding protocol, negotiated as part of the Treaty of Amsterdam. Scepticism towards EU policies has, therefore, long been a central part of the UK's relations with the EU. This scepticism was made even more evident in the context of the Brexit referendum, in which a small majority voted to leave the EU. Historically, the UK-EU relationship has been particularly ambiguous, and this plays out in the UK's bioborders regime. Enhancing the UK's ability to identify foreign criminals, while still enforcing limitations to data exchange aimed at protecting the UK's citizens, emerges as one of the major motifs and notions of nationhood mobilized in the compliance with the Prüm system.

\section{National DNA Database Development}

DNA fingerprinting was discovered in the UK in 1985 by Professor Sir Alec Jeffreys at the University of Leicester, and the UK was the first country to create a national forensic DNA database (in 1995)-the NDNAD. This database contains DNA data from all the police forces in England and Wales, as well as data from the Northern Ireland DNA Database (NIDNAD) and the Scottish DNA Database (SDNAD), and DNA profiles from the Crown Dependencies ${ }^{7}$ (Amankwaa \& McCartney, 2018; Skinner \& Wienroth, 2019). Regarding its legislative framework, the UK operates an adversarial legal system-which makes it different

\footnotetext{
${ }^{7}$ Namely, Isle of Man, the Bailiwick of Jersey and the Bailiwick of Guernsey.
} 
from the continental cases considered in this book, which have in common to different degrees an inquisitorial tradition. In the UK's system, the court acts as a referee between the prosecution and the defence. In the UK, the first statute governing the NDNAD was the Criminal Justice and Public Order Act 1994, which enabled the databasing of DNA profiles. The Act permitted DNA records of all individuals convicted of a recordable offence to be retained indefinitely. Although samples from suspects were collected, the Act required that those who had never been convicted of a criminal offence should be considered 'innocent' and thus that their DNA records should be deleted after the conclusion of an investigation or any proceedings (Amankwaa \& McCartney, 2018).

However, subsequent legislation supported the expansion of the NDNAD: the Criminal Justice and Police Act of 2001 allowed all samples collected to be retained indefinitely, irrespective of whether the person had been acquitted. This further expanded the collection of DNA samples and profiles by including in the database one-time suspects who may never have been charged with a recordable offence (Williams \& Johnson, 2008). Another amendment also allowed samples from volunteers taking part in mass screenings to be retained indefinitely. The Criminal Justice Act of 2003 further extended police powers by allowing DNA samples to be taken without consent from anyone arrested on suspicion of a recordable offence and to be kept indefinitely (Amelung \& Machado, 2019).

Despite these moves towards expansion, there was scant public debate on how the NDNAD posed challenges to the protection of human rights (Downey et al., 2012). The NDNAD only began to be perceived and discussed by mass media and politicians as a potential danger to the civil liberties of British citizens in the aftermath of the ' $\mathrm{S}$. and Marper' case. 'S. ${ }^{8}$ was 12 years old when he was arrested for attempted robbery in January 2001 and was cleared 5 months later. Michael Marper was arrested in March 2001 and charged with harassing his partner; the case was discontinued. Both S. and Marper's DNA were taken and added to the NDNAD; after their release, they applied for the removal of their profiles. Their applications were rejected by the British Appeal Courts on the grounds that the inclusion and removal criteria of the NDNAD at the time allowed the profiles of persons who had been arrested but not convicted of a crime to be retained. S. and Marper then resorted to the European Court of Human Rights, which held that retaining the DNA samples of

\footnotetext{
${ }^{8}$ Due to privacy protection issues, he was named in court only as $S$.
} 
individuals who were arrested but later acquitted or who had the charges against them dropped was a violation of the right to privacy under the European Convention on Human Rights. Consequently, the European Court forced the NDNAD to destroy the samples of non-convicted people (Amankwaa \& McCartney, 2018; Amelung \& Machado, 2019). The $S$. and Marper case, thereby, provided a landmark that oriented the possibilities and limitations of using forensic DNA.

The repercussions of the European Court's decision led to the amendment of the laws governing the collection, use and retention of forensic DNA in the UK through the Protection of Freedoms Act 2012 (PoFA), implemented in October 2013. In summary, the PoFA defined that DNA samples must be destroyed after profiling or within six months of their collection; DNA profiles of convicted individuals could be held indefinitely; and profiles from innocent individuals must be deleted after the conclusion of an investigation or any proceedings. Exceptions to these rules included temporal profile retention periods for some first-time convicted minors, those charged or arrested for a qualifying (serious) offence, those issued with a penalty notice for disorder or on national security grounds (Amankwaa \& McCartney, 2018, p. 119). Since the implementation of the PoFA, over 1.7 million forensic DNA profiles from innocent individuals have been deleted, and over 7.7 million DNA samples have been destroyed (Amankwaa \& McCartney, 2018, p. 119). Such deletion has, however, received relatively little public attention (Skinner \& Wienroth, 2019). As noted by David Skinner and Matthias Wienroth:

The story of the NDNAD is intriguing in part because of what it reveals about the difficulties of enacting the results of legal, political and ethical deliberations about the scope and format of this type of collection, but also how such deliberative infrastructures and discourses can emerge in order to prevent, ameliorate or reframe processes of ending [of genetic collections]. (Skinner \& Wienroth, 2019, p. 101)

Since October 2012, the Home Office has been in charge of the management of the technical database infrastructure of the NDNAD, which means that it is under police custody. In terms of software, the NDNAD uses a self-developed programme (ENFSI, 2017). According to the NDNAD Strategy Board's annual report, 36 vetted Home Office staff have access to it (Home Office, 2019). Police forces own the profile 
records in the database and receive notification of any matches, but they do not have access to it (Home Office, 2019).

A particularity of the UK case that had a direct impact on the technical database infrastructure was the closure in 2012 of the Forensic Science Service (FSS), the public provider of scientific support to police investigations in the UK. The main reason for the Service's closure was linked to its considerable financial losses (Lawless, 2011). The closure meant that DNA profiling services were transferred to private providers, although some forensic scientific work remains the preserve of the police forces themselves, through in-house facilities (Lawless, 2011).

In terms of organizational imperatives and principles, as a nation-state that holds one of the world's largest DNA databases, the UK has been dealing systematically with the societal effects triggered by various ethical controversies. Those issues relate to the size of the database, in terms of its proportion of the entire population (Amankwaa, 2018), as well as its scope. As previously explained, until the $S$. and Marper case, the NDNAD included profiles of individuals who had been acquitted of a crime. The expansion of the number of profiles and the subsequent decisions about the database engendered significant public debate (Skinner \& Wienroth, 2019). Other controversies that have been heavily discussed within the framework of the NDNAD relate to the racialization of the database, for instance, to the overrepresentation of black people in the database population and to the classification of DNA profiles according to 'ethnic appearance' (Human Genetics Commission, 2009; Nuffield Council on Bioethics, 2007; Skinner, 2013, 2018). Civil society organizations, such as GeneWatch, Liberty and Black Mental Health, have also articulated concerns about an overemphasis on genetic explanations that relate to criminality, the retention of children's DNA and the overrepresentation of specific minorities (Amelung \& Machado, 2019; Skinner, 2012).

Such ethical controversies, coupled with public protests and criticism, have stimulated the development of stricter regulation, designed to protect citizens' rights; by extension, they have also motivated particular governance forms aimed at responding to certain needs for stronger public accountability and transparency (Amelung \& Machado, 2019; Granja \& Machado, 2019). Nowadays, the use of forensic DNA technologies is overseen by a partnership of boards and appointed experts. 
The NDNAD Strategy Board ${ }^{9}$ provides governance and oversight over the retention and destruction of DNA profiles and rules for the database; it also produces reports and statistics concerning the operation of the NDNAD.

The UK NDNAD Ethics Group was created in 2007 and operated as a non-statutory body, providing independent advice on ethical issues around the operation of the database to Home Office ministers and the NDNAD Strategy Board. The NDNAD Ethics Group's role changed in 2016 with the introduction of the new National Forensic Science Strategy, which defined a wider role for the Group as part of the enhanced governance structure for the forensics system (Amelung \& Machado, 2019). The Ethics Group was replaced by the Biometrics and Forensics Ethics Group in 2017. The goal of the group includes consideration of the ethical impact on society, groups and individuals of the collection, retention and use of human samples and biometric identifiers for purposes that fall within the purview of the Home Office. More particularly, the Biometrics and Forensics Ethics Group considers the application, operation, research and services related to technologies that produce biometric and forensic data and identifiers.

The Forensic Science Regulator, a role created in 2008, ensures that the provision of forensic science services across the criminal justice system is subject to appropriate scientific quality standards. The Biometrics Commissioner's role is to keep under review the retention and use by the police of DNA samples, DNA profiles and fingerprints. Although this role was mentioned in the Protection of Freedoms Act (2012), it was formally established only in 2013. As 'independent' expert authorities, the Forensic Science Regulator and the Biometrics Commissioner contribute to advising the Home Office.

In terms of public understandings of DNA databases and forensic genetics in the UK, there is a substantial body of literature, especially when compared with other countries under study. Williams and Johnson (2004) distinguish between three types of representations of DNA detected across the UK's societal stakeholders' views: (i) 'genetic

\footnotetext{
${ }^{9}$ The Strategy Board comprises representatives of the National Police Chiefs' Council, the Home Office, the DNA Ethics Group, the Association of Police and Crime Commissioners, the Forensic Science Regulator (or her representative), the Information Commissioner's Office, the Biometrics Commissioner (or his representative), representatives from the police and devolved administrations of Scotland and Northern Ireland and such other members as may be invited (Granja \& Machado, 2019).
} 
exceptionalism', stressing the unique character of genetic material; (ii) 'genomic minimalism' emphasizing the mundane character of non-coding sequences of DNA; (iii) 'biometric pragmatism' that distinguishes between the legitimate and illegitimate sources and uses of DNA for forensic purposes. Other scholars have focused on the perspectives of lay citizens (Anderson, Stackhouse, Shaw, \& Iredale, 2011; Stackhouse, Anderson, Shaw, \& Iredale, 2010; Wilson-Kovacs, Wyatt, \& Hauskeller, 2012). In a review of studies on public perceptions of forensic DNA retention in the UK and around the world, Amankwaa (2018) shows that there is considerable public support for the retention of DNA for criminal investigation purposes since the public believe that DNA databases have strong crimesolving abilities. Reported concerns are mainly related to the potential misuse of DNA and the retention of DNA from innocent individuals (Amankwaa, 2018).

The UK has been a pioneer in the development of DNA technology. For example, in 2002, the UK was the first country to implement familial searching for criminal investigation purposes using the NDNAD (Haimes, 2006; Prainsack, 2010). The particular circumstances in which familial searches are performed are described as 'operationally sensitive' and are, therefore, not available publicly (Nuffield Council on Bioethics, 2007, p. 78). Based on interviews conducted with key stakeholders in the UK, Rafaela Granja and Helena Machado argue that the use of familial searching is regulated through exceptionality. This entails giving consideration to the seriousness of a criminal case, other avenues of investigation and what is contemplated as ethically acceptable (Granja \& Machado, 2019).

The now-closed UK's Forensic Science Service was also pioneering in the area of forensic DNA phenotyping (FDP), as it developed the first FDP test, for detecting red hair. Similarly to other countries, the UK does not have explicit legislation governing FDP; instead, the use of FDP is overseen on a case-by-case basis by various regulatory oversight bodies (Samuel \& Prainsack, 2018).

\section{Bordering Practices and Ordering Transnational DNA Data Exchange}

The UK's ambiguous bordering practices concerning crime control can be traced back to the decision on the Treaty of Lisbon. When the Treaty of Lisbon-which aimed to provide a stronger basis for the development of 
a criminal justice area while stipulating new powers for the European Parliament ${ }^{10}$ - was being negotiated, the UK mobilized Article 10 of Protocol 36. This allowed the UK five years in which to decide whether or not it would continue to be bound by the police and criminal justice cooperation prescribed within the Treaty. This implied that the UK had until May 2014 to decide whether to exercise its 'opt-out' option in matters concerning justice and home affairs (McCartney, 2013, p. 546). In July 2013, the government decided to opt out of police and criminal justice measures, which included the Prüm Decisions; its decision took effect on 1 December 2014. The UK government, however, displayed an ambiguous position towards bordering practices: that same day it also decided to rejoin 35 measures considered to be in the nation's interests (Home Office, 2015).

The decision to remain out of Prüm was formally justified by the government's belief that the implementation of Prüm's technical requirements would be a lengthy and expensive process. The time it would take to establish Prüm raised concerns over the possibility that the EU Commission would initiate infringement proceedings, which involved substantial fines against Member States that did not implement measures or did so incorrectly. Also, the government estimated that it would cost $£ 31$ million to establish the Prüm system in the UK (McCartney, 2013). As stated by the Home Secretary in Parliament on 10 July 2014:

One measure that we have successfully resisted joining is Prüm (...). I have been clear in the House previously that we have neither the time nor the money to implement Prüm by 1 December. I have said that it will be senseless for us to rejoin it now and risk being infracted. (Home Office, 2015) [italics added]

The government also argued that Prüm's 'technical requirements' were out of date (HM Government, 2014) and that the size of the UK database - as one of the largest DNA databases in the EU-might lead to a disproportionate number of requests from other EU states (HM Government, 2014). It is, nevertheless, clear that the decision to opt out reflects a broader framework of scepticism towards the EU and intentional rebordering attempts aimed at countering the EU's doctrine of borderless

\footnotetext{
${ }^{10}$ See http://www.europarl.europa.eu/factsheets/en/sheet/155/judicial-cooperationin-criminal-matters (last visited 8 November 2019).
} 
data flow. As stated by Carole McCartney, 'The decision to use the optout has been cast as "taking back" powers from the EU. Areas such as the criminal law, policing and sentencing are seen as "last bastions of national state power"' (McCartney, 2013, p. 549).

Despite the government's initial decision, the UK's ambiguous bordering practices have evolved in different phases aimed at finding a balance between the narratives of the benefits of data exchange for national security and the need to maintain control of costs and ownership of data. Following the advice from law enforcement agencies that Prüm would offer the UK significant potential benefits for the investigation and prevention of crime, the government agreed to conduct a small Prüm-style pilot test on the exchange of DNA profiles, after which the parliament would make a final decision on whether or not to rejoin the Prüm system.

The Prüm-style pilot project began on 30 September 2015 and aimed to explore how the exchange of the UK's genetic data across borders could be effected, what the technical challenges of implementation would be and what safeguards should be in place. The Netherlands, Spain, France and Germany participated in the UK's pilot test. Close to 2500 DNA profiles from forces across the UK were sent, and there were a total of 118 hits (Home Office, 2015). A report entitled Prüm Business and Implementation Case (Home Office, 2015) was drafted afterwards to analyse in depth the three options open to the UK: to maintain the status quo and remain out of Prüm, to rejoin the Prüm Decisions, or to develop an alternative mechanism for police cooperation and data exchange. The report was then debated in the House of Commons and in the House of Lords in December 2015. The debates were heavily influenced by the recent terrorist attacks in Paris (November 2015) and, consequently, by the perceived need to step up transnational police cooperation for identifying and convicting foreign criminals.

The Prüm Business and Implementation Case (Home Office, 2015) stated that the benefits of the UK fully implementing the Prüm Decisions would be (i) simplified processes for requesting information and/or data; (ii) efficiency gains in international searches; (iii) an increase in resolution of unsolved crimes; (iv) an improved response rate to requests for information associated with crime and terrorism; (v) ability to exploit the UK's investment in other data systems; (vi) improved detection of volume crimes and serious crimes; (vii) an enhanced crime and terrorism intelligence picture; (vii) access to EURODAC for criminal investigation searches (EURODAC is inaccessible unless Prüm searches have already 
taken place). Theresa May, then Secretary of State for the Home Office, also outlined the benefits brought by the UK's inclusion in Prüm when she kicked off the debate in the House of Commons on 8 December 2015:

I beg to move, that this House, wishing to see serious crimes solved, to counter terrorism and to see foreign criminals prosecuted and deported, supports opting in to the Prüm Decisions; notes the views of senior law enforcement officers that the Prüm Decisions are an important aid to tackling crime; notes the success of a pilot that demonstrated that the Prüm Decisions mechanism is both swift and effective. ${ }^{11}$

The risks and associated recommendations for integration with Prüm were also outlined. The protection of the civil liberties of UK citizens, doubts about other countries' practices in processing DNA data and concerns about the extension of the jurisdiction of the Court of Justice of the European Union (CJEU) took front stage both in the report and the debates in the Houses of Commons and Lords. As stated by Sir William Cash, Chair of the European Scrutiny Committee, House of Commons, during the debate:

The Government say that they will apply higher technical standards than required by Prüm (...) for the UK's DNA and fingerprint databases, but we should recall that DNA profiles and fingerprints of British citizens may be held on foreign databases, which may be subject to less rigorous standards than those proposed by the Government. All in all, this is not a motion that should be passed, for the reasons that I have given: it interferes with parliamentary sovereignty, it extends the range of the European Court (...) For many of us, this is a step too far. ${ }^{12}$ [Italics added]

It is important to note that scepticism and doubts about other countries' practices and standards in processing DNA data are not unique to the UK. Machado and Granja, analysing the views of Prüm National Contact Points working in Prüm Step 1, outlined that forensic practitioners remain doubtful that ethically sound science is conducted in other

\footnotetext{
${ }^{11}$ House of Commons Hansard Debates for 8 December 2015. Available at https://publications.parliament.uk/pa/cm201516/cmhansrd/cm151208/debtext/151208-0003. htm (last visited 6 December 2019).

${ }^{12}$ House of Commons Hansard Debates for 8 December 2015. Available at https://publications.parliament.uk/pa/cm201516/cmhansrd/cm151208/debtext/151208-0003. htm (last visited 6 December 2019).
} 
countries (Machado \& Granja, 2018). In order to diminish the risk of innocent UK citizens being targeted, the Prüm Business and Implementation Case suggested that, if the UK's parliament were to opt in to Prüm, only the DNA data and fingerprints of convicted individuals should be made available for transnational exchange. This caveat reiterated a strong notion of protection of the UK's nationhood and citizens:

For example, the Government would legislate to ensure that other Member States could only search against UK held DNA profiles and fingerprints of those actually convicted of a crime. This would help to avoid innocent British citizens becoming caught up in overseas investigations. (Home Office, 2015)

Other risks mentioned both in the report and during the parliamentary debates related to the possibility of DNA adventitious matches. Given that DNA profile matches of six and seven loci have a high probability of being false positives, the report stated that only crime scene profiles with more than eight loci should be shared with the other Member States on the UK Prüm exchange. In addition, it also suggested that the UK should exchange DNA profiles with the other Member States, but that demographic data should only be exchanged following a match of ten or more loci.

Forensic practitioners working within Prüm operational countries also view the occurrence of a large number of false positives in transnational data exchange as ethically problematic (Machado \& Granja, 2018). Thus, despite being framed by high levels of scepticism towards EU policies, the UK's assessment of the risks involved in transnational DNA data exchange within Prüm accords with what practitioners already working with Prüm also perceive as risks (Machado \& Granja, 2019).

Finally, the report mentioned two further risks regarding (i) the volume of work brought by Prüm, especially taking into account that the UK has one of the largest forensic DNA databases, and (ii) the cost of implementation, which the report revised down to $£ 13.5$ million from the previously indicated $£ 31$ million (Home Office, 2015).

Following the publication of the Prüm Business and Implementation Case (Home Office, 2015), in December 2015, the UK decided to opt back in to the Prüm system. However, it did so on condition that the dynamics of data border-crossings would be restricted to 'only a subset of the relevant national DNA and fingerprint databases, containing data 
relating to individuals convicted of recordable offences, will be made available for searching by other participating States, and that the higher UK scientific standards will be applied to matches in the UK'. ${ }^{13}$ Enhancing the UK's ability to identify foreign criminals while still enforcing limitations to data exchange aimed at protecting UK citizens thus emerges as one of the major motifs and notions of nationhood mobilized in complying with the Prüm system.

The UK adopted a protectionist view of data ownership by reducing the type of data made available for transnational DNA exchange. However, this position, although more clearly evidenced in the UK case, is not limited to the UK case. In Portugal — and most likely in other countries-a protectionist view of data ownership resulted from the country's own restricted legislative framework (see Chap. 7). Protectionist views of data ownership are also evidenced by the variable number of data categories made available by each Prüm operational country (see Chap. 3 ).

On 6 June 2019, the EU Justice and Home Affairs Council adopted a Council Implementing Decision officially launching the automated exchange of DNA profiles between other Prüm participants and the UK. Since the NDNAD uses self-developed software (ENFSI, 2017), in order to make transnational exchange viable, CODIS had to be installed (Council of the European Union, 2018). As well as authorizing DNA exchanges to commence from 14 June 2019, the Decision also stated the Council's request that the UK review its policy of excluding suspects' profiles from automated DNA data exchange within 12 months. Furthermore, it outlined that if the operational experience acquired with Prüm DNA data exchange within the first 12 months has not led the UK to notify the Council that it has reviewed its policy, the Council should re-evaluate the situation with a view to the continuation or termination of DNA Prüm automated exchange with the UK' (Council of the European Union, 2019).

Responding to the imposed deadline to review the policy of limiting data exchange via Prüm to profiles from convicted offenders, crime stains and unidentified human remains, on 15 June 2020, James Brokenshire, the Minister of State for Security, announced that it is the government's intention to begin exchanging suspects' data via Prüm. ${ }^{14}$ Such decision has

\footnotetext{
${ }^{13}$ https://publications.parliament.uk/pa/cm201719/cmselect/cmeuleg/301lxx/30106.htm (last visited 8 November 2019).

${ }^{14}$ Prüm-Data Sharing Update: Written statement-HCWS290 https://www.parliament.uk/business/publications/written-questions-answers-statements/written-statement/ Commons/2020-06-15/HCWS290/ (last visited on 19 June 2020).
} 
been, according to the UK governmental view expressed in the written public statement, based upon a balance between benefits and risks associated with exchanging suspects' data, maintaining a concrete focus on the protection of UK citizens:

In considering whether to include suspects' data, the Government has carefully balanced the potential public protection benefits against concerns that a UK citizen could be caught up inappropriately in criminal investigations in $E U$ Member States and has considered the effectiveness of the safeguards put in place to prevent such instances occurring. In light of the benefits reaped from exchanging DNA since July 2019 and the way in which the safeguards have been applied, the Government has concluded that the important public safety benefits in exchanging suspects' data outweigh the risks associating with sharing it. [Italics added] ${ }^{15}$

Such decision to exchange suspects' data within Prüm may be interpreted as a concession to the EU requirement to adopt logics of reciprocal data exchange. As EU officials have previously reported a perceived 'lack of reciprocity' in how the UK cooperated within Prüm (Brunsden \& Peel, 2020 ), the decision to review the policy of limiting data exchange via Prüm seems to be a strategic move to keep doors open for post-Brexit participation in Prüm-like agreements, as the UK's current participation in the Prüm system ends on 31 December 2020, when the Brexit transition period expires. The UK has already stated interest in ensuring the continuity of law enforcement and judicial cooperation in criminal matters. In particular, the report entitled 'The Future Relationship with the EU: The UK's Approach to Negotiations' (HM Government, 2020) states that the UK is interested in discussing an agreement. In terms of the exchange of DNA, fingerprints and vehicle registration data, the report states that

The agreement should provide similar capabilities to those currently delivered through the Prüm system, drawing on the precedent for such cooperation between the EU, Norway and Iceland as well as between the EU and Switzerland and Liechtenstein. These precedents include a political dispute

\footnotetext{
${ }^{15}$ Prüm-Data Sharing Update: Written statement-HCWS290 https://www.parliament.uk/business/publications/written-questions-answers-statements/written-statement/ Commons/2020-06-15/HCWS290/ (last visited on 19 June 2020).
} 
resolution mechanism with no jurisdiction in those third countries for the CJEU. (HM Government, 2020, p. 26)

The UK case thereby serves as an example to learn about an ambignous mode of debordering. Its ambiguous nature is the result of the government's changing position regarding the maintenance or suspension of borders for data crossing. In 2014, there was a decision to opt out of the Prüm Decisions. In 2015, after a Prüm-style pilot project run with other EU Member States, the UK decided to opt in. The UK therefore enacted circumscribed debordering practices by agreeing to participate in data exchange across the EU and thereby expanding the data flows bounded to the own nation-state's bioborders. However, the decision to deborder was made on the condition that limits be imposed on other EU countries' access to the UK's data, therefore reflecting rebordering attempts anchored upon restrictive bioborders. However, in light of the negotiating scenario caused by Brexit, limits to data exchange have been recently reduced. The UK's debordering practices - fuelled by claims to access 'foreign' datathereby co-exist with rebordering attempts aimed at ensuring adequate protection of 'own' data and national citizens. Additionally, the UK case reveals the politics of (non)belonging entangled with biobordering dynamics. It does so in the sense of negotiating who is exposed and who needs to be protected from exposure to international police collaboration.

\section{REFERENCES}

Amankwaa, A. O. (2018). Forensic DNA retention: Public perspective studies in the United Kingdom and around the world. Science \& Justice, 58(6), 455-464. https://doi.org/10.1016/j.scijus.2018.05.002

Amankwaa, A. O., \& McCartney, C. (2018). The UK national DNA database: Implementation of the protection of freedoms act 2012. Forensic Science International, 284, 117-128. https://doi.org/10.1016/j.forsciint.2017. 12.041

Amelung, N., \& Machado, H. (2019). Affected for good or for evil: The formation of issue-publics that relate to the UK National DNA Database. Public Understanding of Science, 28(5), 590-605. https://doi.org/10.1177/0963 662519836346

Anderson, C., Stackhouse, R. S., Shaw, A., \& Iredale, R. (2011). The national DNA database on trial: Engaging young people in South Wales with genetics. 
Public Understanding of Science, 20(2), 146-162. https://doi. org/10.1177/0963662510375793

Brunsden, J., \& Peel, M. (2020, February 2). EU to pressure post-Brexit Britain over DNA sharing. Financial Times. Retrieved June 23, 2020, from https:// www.ft.com/content/87e84lf4-4406-1lea-a43a-c4b328d906lc.

Council of the European Union. (2018). Working Party on Information Exchange and Data Protection (DAPIX) - Implementation of the provisions on information exchange of the 'Prüm Decisions'.

Council of the European Union. (2019). Council Implementing Decision (EU) 2019/968 of 6 June 2019 on the launch of automated data exchange with regard to DNA data in the United Kingdom, Official Journal of the European Union.

Council of the European Union. (2020). Working party on JHA Information Exchange (IXIM) 5322/19.

Downey, J., Stephens, M., \& Flaherty, J. (2012). The 'sluice-gate' public sphere and the national DNA database in the UK. Media, Culture of Society, 34(4), 439-456. https://doi.org/10.1177/0163443711436357

ENFSI. (2017). DNA database management. Review and recommendation. Retrieved from http://enfsi.eu/wp-content/uploads/2016/09/final_version_enfsi_2016_document_on_dna-database_management_0.pdf

Granja, R., \& Machado, H. (2019). Ethical controversies of familial searching: The views of stakeholders in the United Kingdom and in Poland. Science, Technology, \& Human Values, 44(6), 1068-1092. https://doi. org/10.1177/0162243919828219

Haimes, E. (2006). Social and ethical issues in the use of familial searching in forensic investigations: Insights from family and kinship studies. Journal of Law, Medicine \& Ethics, 34(2), 263-276. https://doi.org/10.1111/ j.1748-720X.2006.00032.x

HM Government. (2014). Decision pursuant to Article 10(5) of Protocol 36 to The Treaty on the Functioning of the European Union.

HM Government. (2020). The future relationship with the EU: The UK's approach to negotiations. Retrieved from https://assets.publishing.service.gov.uk/government/uploads/system/uploads/attachment_data/file/868874/ The_Future_Relationship_with_the_EU.pdf

Home Office. (2015). Prüm business and implementation case. Retrieved from https://www.gov.uk/government/publications/prum-business-andimplementation-case.

Home Office. (2019). National DNA Database Strategy Board Annual Report 2017/18. Retrieved from https://www.gov.uk/government/publications/ national-dna-database-annual-report-2017-to-2018 
Human Genetics Commission. (2009). Nothing to hide, nothing to fear? Balancing individual rights and the public interest in the governance and use of the National DNA Database.

Johnson, P., \& Williams, R. (2007). Internationalizing new technologies of crime control: Forensic DNA databasing and datasharing in the European Union. Policing o Society, 17(2), 103-118. https://doi.org/10.1080/10439 460701302669

Lawless, C. (2011). Policing markets: The contested shaping of neo-liberal forensic science. British Journal of Criminology, 51(4), 671-689. https://doi. org/10.1093/bjc/azr025

Machado, H., \& Granja, R. (2018). Ethics in transnational forensic DNA data exchange in the EU: Constructing boundaries and managing controversies. Science as Culture, 27(2), 242-264. https://doi.org/10.1080/0950543 1.2018 .1425385

Machado, H., \& Granja, R. (2019). Risks and benefits of transnational exchange of forensic DNA data in the EU: The views of professionals operating the Prüm system. Journal of Forensic and Legal Medicine, 68, 101872. https://doi. org/10.1016/J.JFLM.2019.101872

McCartney, C. (2013). Opting in and opting out: Doing the hokey cokey with EU policing and judicial cooperation. The Journal of Criminal Law, 77, 543-561. https://doi.org/10.1350/jcla.2013.77.6.879

Nuffield Council on Bioethics. (2007). The forensic use of bioinformation: Ethical issues.

Prainsack, B. (2010). Key issues in DNA profiling and databasing: Implications for governance. In R. Hindmarsh \& B. Prainsack (Eds.), Genetic suspects: Global governance of forensic DNA profiling and databasing (pp. 153-174). University Press.

Samuel, G., \& Prainsack, B. (2018). The regulatory landscape of forensic DNA phenotyping in Europe. Retrieved from http://www.visage-h2020.eu/Report_ regulatory_landscape_FDP_in_Europe2.pdf

Skinner, D. (2012). Mobile identities and fixed categories: Forensic DNA and the politics of racialized data. In K. Schramm, D. Skinner, \& R. Rottenburg (Eds.), Identity politics and the new genetics: Re/creating categories of difference and belonging (pp. 53-78). Berghahn Books.

Skinner, D. (2013). 'The NDNAD has no ability in itself to be discriminatory': Ethnicity and the governance of the UK National DNA Database. Sociology, 47(5), 976-992. https://doi.org/10.1177/0038038513493539

Skinner, D. (2018). Race, Racism and identification in the era of technosecurity. Science as Culture, 1-23. https://doi.org/10.1080/09505431.2018.1523887 
Skinner, D., \& Wienroth, M. (2019). Was this an ending? The destruction of samples and deletion of records from the UK police national DNA database. BJHS Themes, 1-23. https://doi.org/10.1017/bjt.2019.7

Stackhouse, R., Anderson, C., Shaw, A. J., \& Iredale, R. (2010). Avoiding the 'usual suspects: Young people's views of the national DNA database. New Genetics and Society, 29(2), 149-166. https://doi.org/10.1080/1463677 8.2010 .484234

Williams, R., \& Johnson, P. (2004). 'Wonderment and dread': Representations of DNA in ethical disputes about forensic DNA databases. New Genetics and Society, 23(2), 205-223. https://doi.org/10.1080/1463677042000237035

Williams, R., \& Johnson, P. (2008). Genetic policing: The use of DNA in criminal investigations. Cullompton: Willan Publishing.

Wilson-Kovacs, D., Wyatt, D., \& Hauskeller, C. (2012). A Faustian bargain?' Public voices on forensic DNA technologies and the national DNA database. New Genetics and Society, 31(3), 285-298.

Open Access This chapter is licensed under the terms of the Creative Commons Attribution 4.0 International License (http://creativecommons.org/licenses/ by $/ 4.0 /$ ), which permits use, sharing, adaptation, distribution and reproduction in any medium or format, as long as you give appropriate credit to the original author(s) and the source, provide a link to the Creative Commons licence and indicate if changes were made.

The images or other third party material in this chapter are included in the chapter's Creative Commons licence, unless indicated otherwise in a credit line to the material. If material is not included in the chapter's Creative Commons licence and your intended use is not permitted by statutory regulation or exceeds the permitted use, you will need to obtain permission directly from the copyright holder.

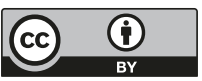

